\title{
Functional display of heterotetrameric human protein kinase CK2 on Escherichia coli: a novel tool for drug discovery
}

\author{
Andreas Gratz ${ }^{1}$, Andre Bollacke', Sara Stephan², Christian Nienberg ${ }^{1}$, Marc Le Borgne ${ }^{3}$, Claudia Götz ${ }^{4}$ \\ and Joachim Jose ${ }^{1 *}$
}

\begin{abstract}
Background: Human protein kinase CK2 represents a novel therapeutic target for neoplastic diseases. Inhibitors are in need to explore the druggability and the therapeutic options of this enzyme. A bottleneck in the search for new inhibitors is the availability of the target for testing. Therefore an assay was developed to provide easy access to CK2 for discovery of novel inhibitors.

Results: Autodisplay was used to present human CK2 on the surface of Escherichia coli. Heterotetrameric CK2 consists of two subunits, $\alpha$ and $\beta$, which were displayed individually on the surface. Co-display of CK2 $\alpha$ and CK2 $\beta$ on the cell surface led to the formation of functional holoenzyme, as demonstrated by $\mathrm{NaCl}$ dependency of enzymatic activity, which differs from that of the catalytic subunit CK2 $\alpha$ without $\beta$. In addition interaction of CK2 $\alpha$ and CK2 $\beta$ at the cell surface was confirmed by co-immunoprecipitation assays. Surface displayed CK2 holoenzyme enabled an easy $I_{50}$ value determination. The $\mathrm{IC}_{50}$ values for the known CK2 inhibitors TBB and Silmitasertib were determined to be 50 and $3.3 \mathrm{nM}$, respectively.

Conclusion: Surface-displayed CK2 $\alpha$ and CK2 $\beta$ assembled on the cell surface of E. coli to an active tetrameric holoenzyme. The whole-cell CK2 autodisplay assay as developed is suitable for inhibition studies. Furthermore, it can be used to determine quantitative $C K 2$ inhibition data such as $I C_{50}$ values. In summary, this is the first report on the functional surface display of a heterotetrameric enzyme on E. coli.
\end{abstract}

Keywords: Assay, Autodisplay, CK2, Heterotetramer, Protein kinase, Screening, Surface display, Drug discovery

\section{Background}

To display a functional protein on the surface of a living cell bears several advantages in comparison to intracellular expression [1]. The protein at the cell surface is freely accessible for any kind of binding or activity studies. This can be applied e.g. in assays that allow to quantify proteinprotein interactions by displaying one partner protein at the cell surface and subsequently add the binding partner protein labeled with a fluorescent dye, and determine

\footnotetext{
*Correspondence: joachim.jose@uni-muenster.de

${ }^{1}$ Institut für Pharmazeutische und Medizinische Chemie, PharmaCampus, Westfälische Wilhelms-Universität Münster, Corrensstr. 48, 48149 Münster, Germany

Full list of author information is available at the end of the article
}

the interaction by quantifying the whole cell fluorescence obtained thereby with the help of flow cytometry [2]. The screening of antibody libraries can be performed in a similar way, when the variants are displayed on the cell surface. The labeled antigen can be used, binding can be quantified by flow cytometry, and finally single cells bearing a distinct variant can be selected by fluorescence activated cell sorting $[3,4]$. Such strategy can also be applied to identify novel enzyme inhibitors, taking into account that inhibitors have a high affinity (or a low dissociation constant) for enzymes they are inhibiting. In such case, peptide libraries displayed on the surface of E. coli can be screened by fluorescence labeled target enzymes, and whole cell fluorescence can be used for selecting strong binding variants $[5,6]$. At this point it needs to be 
emphasized, that the libraries actually consist of different cells of $E$. coli, each displaying a different variant. Moreover one needs to have in mind that binding does not necessarily mean inhibition of the enzyme, but subsequently the selected variants can be tested on enzyme inhibition, and proofed to be a reliable source for novel inhibitors. Beside these activa for screening purposes, the cellular surface display of a protein, namely an enzyme has also advantages in the development of whole cell biocatalysts [7]. Neither the substrate nor the product need to cross a membrane barrier, and the formation of by-products by other enzymes is prevented, as it could appear by whole cell biocatalysts with intracellular enzyme expression. This is in particular an issue in the biocatalytic production of pharmaceuticals. Moreover, being anchored at the cell surface increases enzymatic stability [8], and in case the enzyme needs a membrane environment to be active this can be provided as well $[9,10]$. A disadvantage of whole cell biocatalysts with surface displayed enzymes is, however, that enzymes which need supply of co-factors, e.g. redox co-factors like $\mathrm{NADH}$ or $\mathrm{NAD}^{+}$, are excluded from the regeneration circles, as available in the cytoplasm. For many of the applications mentioned here, autodisplay has been proven to be a helpful tool. In principle, autodisplay is the surface display of a recombinant protein in a Gram-negative bacterium by means of the autotransporter secretion pathway [11-13]. Nevertheless, most of the applications described until now are for the AIDA-I autotransporter to display a recombinant protein on E. coli [1]. One advantage of using the AIDA-I autotransporter for surface display in E. coli is the high number of displayed proteins, which were reported to be in the range of $10^{5}-10^{6}[14,15]$. A second advantage is, that the anchoring domain, the so-called $\beta$-barrel, is not covalently linked to the surface, but can move or "swim" within the plane of the outer membrane. This can lead to a passenger driven dimerization or even multimerization at the cell surface, by simple expression and surface display of the corresponding monomer [16]. More recently it has been sown, that the co-display of a lipase and its specific foldase by AIDA-I leads to an active lipase biocatalyst [17]. This takes again benefit from the motility of the anchoring domains, allowing the lipase and the foldase to get into direct contact at the cell surface. In the present study we displayed human protein kinase CK2 by autodisplay on the surface of $E$. coli. Human protein kinase CK2 is an emerging target for cancer diseases [18, 19]. Despite two inhibitors of the enzymes are in clinical trials phase II at current $[20,21]$ more inhibitors are in need to explore the druggability and the therapeutic options of human CK2 [22]. A bottleneck in the search for new inhibitors is the availability of the target, i.e. human protein kinase CK2 for testing. Protein kinase CK2 is a heterotetramer, consisting of two subunits, a catalytic $\alpha$-subunit (which can be replaced in some case by an $\alpha^{\prime}$-subunit) and a so-called regulatory $\beta$-subunit. We expressed and displayed the $\alpha$ and the $\beta$-subunit of human CK2 separately on the surface of $E$. coli and showed the formation of the tetrameric holoenzyme by measuring an increased kinase activity in comparison to the $\alpha$-subunit being displayed alone, by activity profiling using varying $\mathrm{NaCl}$ concentrations, and by co-immunoprecipitation experiments. Cells of $E$. coli displaying the holoenzyme could be used to determine the inhibition constants of two established CK2 inhibitors. Our results show for the first time, that it is possible to display a heterotretrameric human enzyme in an active form on the surface of E. coli, when using the AIDA-I autotransporter for autodisplay.

\section{Methods}

\section{Bacterial strains and culture conditions}

Escherichia coli BL21(DE3) [23] was used for the expression of autotransporter fusion proteins. Bacteria were routinely grown at $37^{\circ} \mathrm{C}$ in lysogeny broth (LB) containing $50 \mathrm{mg} / \mathrm{L}$ carbenicillin or $30 \mathrm{mg} / \mathrm{L}$ kanamycin or both, depending on the plasmid-encoded antibiotic-resistance factor(s) they carried. For expression and activity studies, LB medium was supplemented with $10 \mu \mathrm{M}$ ethylenediaminetetraacetate (EDTA) and $10 \mathrm{mM}$ 2-mercaptoethanol. Routinely, an E. coli liquid culture was grown overnight, and an aliquot of this culture $(200 \mu \mathrm{L})$ was used to inoculate fresh LB medium $(40 \mathrm{~mL})$. Cells were cultivated at $37^{\circ} \mathrm{C}$ with shaking $(200 \mathrm{rpm})$ until an $\mathrm{OD}_{578}$ of 0.6 was reached. Protein formation was induced by adding isopropyl- $\beta$-D-thiogalactopyranoside (IPTG, $1 \mathrm{mM}$ final concentration) for $60 \mathrm{~min}$ at $30^{\circ} \mathrm{C}$.

\section{Design of autotransporter fusion genes and expression plasmids}

In order to prepare a CK $2 \alpha$-coding passenger domain, human CK2 $\alpha$ cDNA (CSNK2A1) was amplified by PCR using the two oligonucleotides Pr199 (5'-CCA GTC GAC TCG GGA CCC GTG CCA AGC AGG GCC AGA GTT TA-3') and Pr200 (5'-AAG GTA CCC TGC TGA GCG CCA GCG GCA GCT GGA ACA-3') as primers and. The PCR product of $1,187 \mathrm{bp}$ was a sequence without start- and stop codon, flanked by restriction endonuclease recognition sites (a Sall site at the $5^{\prime}$ end and an Acc65I site at the $3^{\prime}$ end). After cleavage with Sall and Acc65I, the fragment was ligated in-frame into an autodisplay plasmid (pBL002) that already contained an autodisplay fusion gene encoding signal peptide, passenger, linker and $\beta$-barrel (Figure 1). The plasmid pBL002 is a derivative of pBL001, which has been described before 


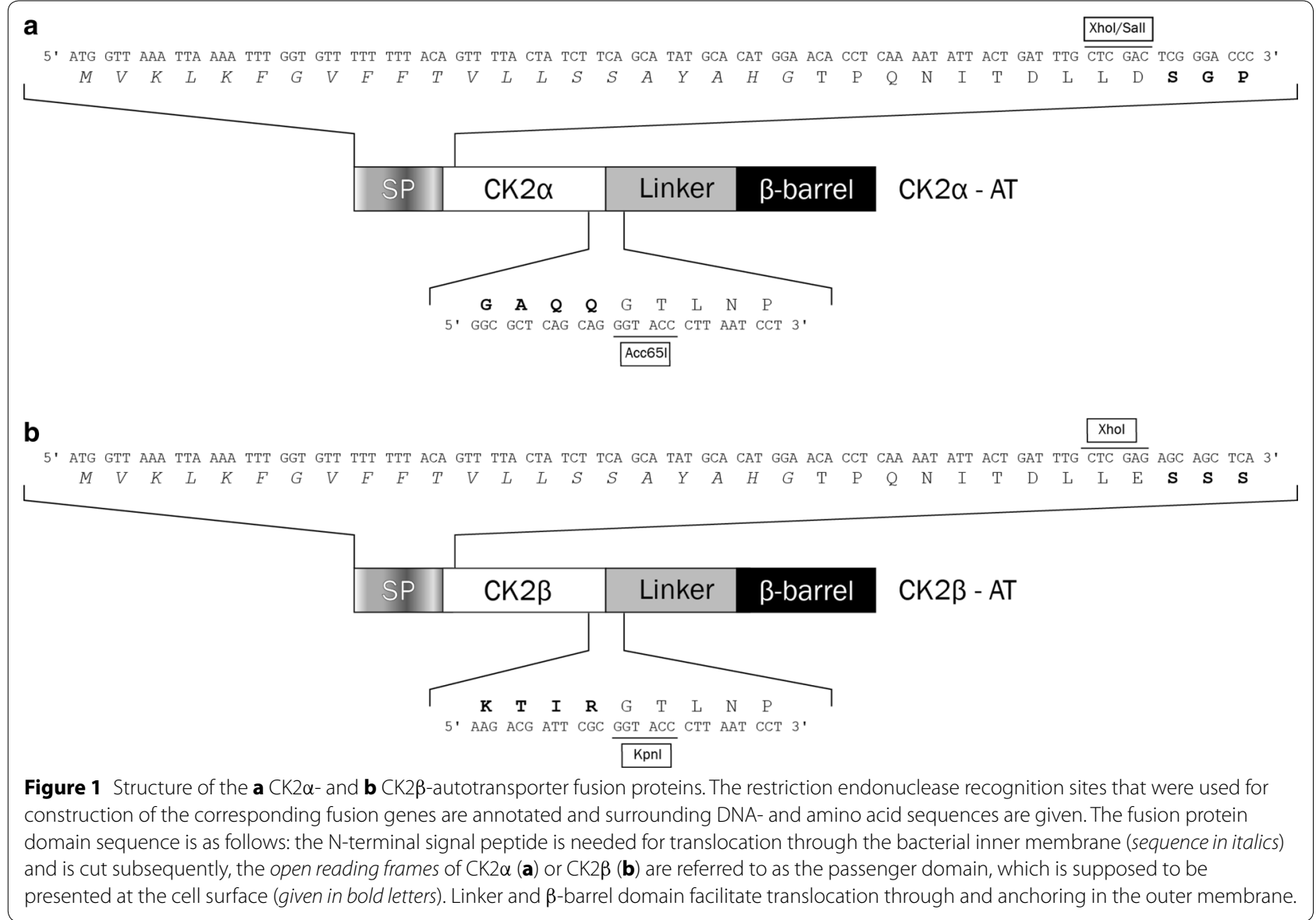

[17], but contained a $1.4 \mathrm{kBp}$ NOX-encoding fragment in the Xhol/KpnI cloning site of pBL001. This passengerencoding domain was removed by a restriction digest with XhoI and Acc65I, yielding a plasmid backbone with compatible ends for the CK2 $\alpha$ insert. The resulting 6,008 bp expression plasmid pCK $2 \alpha$-AT carried a 2,613 bp autotransporter fusion gene for surface display of CK2 $\alpha$. For autodisplay of the $\beta$-subunit of CK2, a previously described autotransporter plasmid pJJ004 [14] was used as expression vector. The adrenodoxin-encoding passenger domain of pJJ004 was replaced by CK2 $\beta$. Therefore, human CK2 $\beta$ cDNA (CSNK2B) was amplified by PCR with primers Pr201 (5'-AAC TCG AGA GCA GCT CAG AGG AGG TGT C-3') and Pr202 (5'-AAG GTA CCG CGA ATC GTC TTG ACT GGG CT-3'). PCR results in CK2 $\beta$ coding DNA fragment devoid of start- and stop-codon but with flanking recognition sites for endonucleases XhoI ( $5^{\prime}$ end) and KpnI ( $3^{\prime}$ end). After cleavage by XhoI and KpnI, the fragment was ligated inframe into $\mathrm{Xhol} / \mathrm{KpnI}$ cleaved vector pJJ004, replacing the adrenodoxin-encoding domain and forming 7,724 bp plasmid pCK $2 \beta$-AT containing the 2,082 bp autotransporter fusion gene.

\section{Outer membrane protein preparation} and trypsin accessibility

After induction of protein formation, E. coli BL21(DE3) strains with either one or two plasmids, or without plasmid as controls, were harvested by centrifugation $\left(3,850 \times g, 4^{\circ} \mathrm{C}, 10 \mathrm{~min}\right)$ and washed twice with $0.2 \mathrm{M}$ Tris/ $\mathrm{HCl}$ ( $\mathrm{pH}$ 8.0). Outer membrane proteins were enriched according to the rapid isolation method of Handke et al. [24] with modifications as described previously [25]. In detail, cells were lysed by adding lysozyme $(0.04 \mathrm{mg} / \mathrm{mL}$ end concentration) in the presence of $10 \mathrm{mM}$ saccharose and $1 \mu \mathrm{M}$ EDTA in a final volume of $1.5 \mathrm{~mL}$ of Tris- $\mathrm{HCl}$ $(0.2 \mathrm{M}, \mathrm{pH} 8)$, followed by an incubation for $10 \mathrm{~min}$ at room temperature. Subsequently aprotinin $(10 \mu \mathrm{g} / \mathrm{mL})$, phenylmethylsulfonyl fluoride (PMSF) $(0.5 \mathrm{mM})$, as well

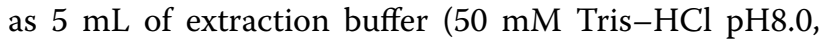
$10 \mathrm{mM} \mathrm{MgCl} 2,2 \%$ Triton X 100) and DNAseI (10 $\mu \mathrm{g} /$ $\mathrm{mL}$ ) were added. The samples were incubated on ice for $30 \mathrm{~min}$ and centrifuged for $5 \mathrm{~min}$ at $4^{\circ} \mathrm{C}(3,850 \times g)$ to remove intact bacteria and large cell debris. The supernatants representing the clarified bacterial lysate were transferred to fresh tubes and centrifuged at higher speed $(38,700 \times g)$ for $30 \mathrm{~min}$ at $4.0^{\circ} \mathrm{C}$ to obtain the membrane 
protein fraction. The resulting supernatants, containing soluble cytoplasmic and periplasmic proteins, were completely aspirated. The pellets were suspended in $10 \mathrm{~mL}$ phosphate-buffered saline (PBS) plus 1\% sarcosyl ( $N$-lauryl sarcosinate, sodium salt) and centrifuged again $\left(38,700 \times g, 60 \mathrm{~min}, 4^{\circ} \mathrm{C}\right)$. The supernatant after this step contained the sarcosyl-soluble cytoplasmic membrane proteins and was completely aspirated. The sediment representing the outer membrane protein fraction was washed twice with $10 \mathrm{~mL}$ of water and taken up in $30 \mu \mathrm{L}$ purified water for SDS-PAGE. Because the outer membrane proteins with surrounding parts of the outer membrane lipids, as obtained thereby, are actually insoluble in water, this represents a suspension of outer membrane vesicles with an average diameter of $180 \mathrm{~nm}$, containing the protein of interest [26]. For whole-cell protease treatment, E. coli cells were harvested, washed and suspended in PBS (1 mL). Trypsin (Fluka, Sigma-Aldrich, Deishofen, Germany) was added to a final concentration of $2.5 \mathrm{~g} / \mathrm{L}$ and cells were incubated for $1 \mathrm{~h}$ at $37^{\circ} \mathrm{C}$. Digestion was stopped by adding $5 \mathrm{~mL} 10 \%$ fetal calf serum (FCS) in $0.2 \mathrm{M}$ Tris $/ \mathrm{HCl}$. After washing the cells twice with $5 \mathrm{~mL}$ $0.2 \mathrm{M}$ Tris $/ \mathrm{HCl}$ the outer membrane fraction was isolated. For SDS-PAGE, the outer membrane sample was dissolved in $20-40 \mu \mathrm{L}$ PBS, depending on the yield. For co-immunoprecipitation it was dissolved in $20-40 \mu \mathrm{L}$ kinase buffer $(50 \mathrm{mM}$ Tris/ $\mathrm{HCl}, 100 \mathrm{mM} \mathrm{NaCl}, 10 \mathrm{mM}$ $\mathrm{MgCl}_{2}, 1 \mathrm{mM} \mathrm{DTT}, \mathrm{pH}$ 7.5). Samples were stored at $4^{\circ} \mathrm{C}$ no longer than 2 days.

\section{SDS-PAGE and Western blot}

Protein samples were diluted with SDS sample buffer $(100 \mu \mathrm{M}$ Tris/HCl, pH 6.8 with $4 \%$ SDS, $0.2 \%$ bromphenol blue and $20 \%$ glycerol). Prior to separation, samples were boiled for 20 min and loaded onto a SDS-Gel containing 7.5 or $10 \%$ acrylamide. PAGE Ruler unstained or prestained protein marker (Fermentas, St. Leon-Roth, Germany) was used as a molecular weight standard. After separation, the gel was stained with Coomassie brilliant blue G250 (Serva, Heidelberg, Germany). For Western blot, samples were separated via SDS-PAGE as described above using PAGE Ruler prestained protein marker (Fermentas, St. Leon-Roth, Germany) and were subsequently transferred onto a PVDF membrane by tank-blotting. After blocking for $1 \mathrm{~h}$ in TBST [TBS (pH 7.4) containing $0.1 \%$ Tween 20 ] supplemented with $5 \%$ dried milk, the blot was incubated for $4 \mathrm{~h}$ with an anti CK2 $\beta$-serum (polyclonal rabbit serum, raised against amino acids 206215 of CK2 $\beta$-subunit, Serum\# 32, [27]), diluted 1:5,000 in TBST, followed by three washing steps with TBST. The membrane was then incubated for $1 \mathrm{~h}$ with the secondary antibody [HRP-coupled anti rabbit IgG (\#AO545, SigmaAldrich, Deishofen, Germany), dilution of 1:10,000 in
TBST] followed by two washing steps with TBST and one with TBS. The immune complex was visualized via chemiluminescence (ImmunoCruz kit, Santa Cruz biotechnology, Heidelberg, Germany).

\section{Co-immunoprecipitation}

$250 \mu \mathrm{g}$ protein A/G magnetic beads (Pierce-Thermo Scientific, Rockford, IL, USA) were mixed with $10 \mu \mathrm{g}$ monoclonal mouse antibody \#1A5, (mouse monoclonal antibody against CK2 $\alpha$ [28]) in $500 \mu \mathrm{L}$ binding buffer $(150 \mathrm{mM} \mathrm{NaCl}, 25 \mathrm{mM}$ Tris/HCl, $1 \mathrm{mM}$ EDTA, $1 \% \mathrm{NP} 40$, $5 \%$ glycerol, $\mathrm{pH} 7.4$ ). After $15 \mathrm{~h}$ at $8^{\circ} \mathrm{C}$ under gently shaking, the supernatant was discarded. The antibody-loaded beads were washed and suspended in $500 \mu \mathrm{L}$ binding buffer and mixed with $25 \mu \mathrm{L}$ E. coli outer membrane fraction. The beads were precipitated after $4 \mathrm{~h}$ at $22^{\circ} \mathrm{C}$ and the supernatant was collected. The beads were washed twice with binding buffer, and once with deionized water, before the immune complex was eluted by heating $\left(95^{\circ} \mathrm{C}\right.$ for $20 \mathrm{~min}$ ) in SDS sample buffer containing $200 \mathrm{mM}$ DTT. Eluted proteins (precipitate) and supernatant were analyzed by SDS-PAGE and Western blot analysis using the polyclonal rabbit anti-CK2 $\beta$-serum [27].

\section{Radiometric whole-cell CK2 activity}

CK2-activity of whole bacterial cells was determined in a radiometric assay usually applied for in vitro testing of the purified enzyme [29]. The transfer of a $\left[{ }^{32} \mathrm{P}\right]$-phosphate from $y\left[{ }^{32} \mathrm{P}\right]$-ATP onto the CK2-specific substrate peptide RRRDDDSDDD [30] is quantified. Here, E. coli cells presenting CK2 subunits were tested, instead of using the purified enzyme. E. coli strains were grown and protein production was induced as described above. Cells were harvested by centrifugation $\left(3,850 \times g, 4^{\circ} \mathrm{C}\right.$, $10 \mathrm{~min}$ ) and washed three times with kinase buffer. Cells were suspended in $20 \mu \mathrm{L}$ kinase buffer to reach an optical density at $578 \mathrm{~nm}\left(\mathrm{OD}_{578}\right)$ of $2.5\left(2.15 \times 10^{8}\right.$ cells/ $\mathrm{mL}$ ). In case of inhibitor testing, cells were suspended in $19.5 \mu \mathrm{L}$ kinase buffer to reach an $\mathrm{OD}_{578}$ of 2.56 . Inhibitor was dissolved in pure DMSO and $0.5 \mu \mathrm{L}$ of inhibitor solution was mixed with the cells and incubated at $37^{\circ} \mathrm{C}$ for $10 \mathrm{~min}$. The reaction was started by adding $30 \mu \mathrm{L}$ hot assay buffer ( $150 \mathrm{mM} \mathrm{NaCl}, 25 \mathrm{mM}$ Tris/HCl, $5 \mathrm{mM}$ $\mathrm{MgCl}_{2}, 0.19 \mathrm{mM}$ substrate peptide RRRDDDSDDD, $0.6 \mu \mathrm{Ci} y\left[{ }^{32} \mathrm{P}\right]$-ATP, $100 \mu \mathrm{M}$ ATP, $\left.\mathrm{pH} 8.5\right)$, diluting the cell suspension to reach $\mathrm{OD}_{578}=1$ in a final volume of $50 \mu \mathrm{L}$ (equals $8.6 \times 10^{7}$ cells $/ \mathrm{mL}$ ). CK2 activity was calculated via measuring the amount of incorporated radioactive phosphate residue in counts per minute (cpm) after binding the peptide to P81 ion exchange paper and scintillation counting. Inhibition by TBB was determined after pre-incubating CK2 with the inhibitor for $10 \mathrm{~min}$ before adding the hot assay buffer. 


\section{Whole-cell CK2 activity assay and inhibition testing by capillary electrophoresis}

The enzymatic activity of surface-displayed protein kinase $\mathrm{CK} 2$ and the $\mathrm{IC}_{50}$-values were determined using a recently published CE-assay [29] with slight modifications. In summary, $78 \mu \mathrm{L}$ of the prepared bacteria suspension in kinase buffer were supplemented with $2 \mu \mathrm{L}$ of the test-compound dissolved in DMSO and incubated for $15 \mathrm{~min}$ at $37^{\circ} \mathrm{C}$ and $400 \mathrm{rpm}$. CK2-reaction was started by the addition of $120 \mu \mathrm{L}$ of assay buffer $(25 \mathrm{mM}$ Tris/HCl, pH 8.5, $150 \mathrm{mM} \mathrm{NaCL}, 5 \mathrm{mM} \mathrm{MgCl}$, $1 \mathrm{mM}$ DTT, $167 \mu \mathrm{M}$ substrate peptide RRRDDDSDDD and $100 \mu \mathrm{M}$ ATP) and was carried out for $60 \mathrm{~min}$ at $37^{\circ} \mathrm{C}$ and $400 \mathrm{rpm}$. Final concentration for the substrate peptide RRRDDDSDDD was $100 \mu \mathrm{M}$ and for ATP $60 \mu \mathrm{M}$ with a cell concentration of $\mathrm{OD}_{578}=2$ (equals $1.72 \times 10^{8}$ cells $/ \mathrm{mL}$ ) in a total volume of $200 \mu \mathrm{L}$. After the removal of CK2-presenting bacteria by centrifugation at 3,850 $\times g$ $\left(10 \mathrm{~min}, 4^{\circ} \mathrm{C}\right.$ ), the supernatant was transferred to a 96 well microplate. CK2-reaction was terminated by lowering to temperature to $4^{\circ} \mathrm{C}$ and complexing divalent cations with $12.5 \mathrm{mM}$ EDTA before it was analyzed by capillary electrophoresis. For the determination of $\mathrm{IC}_{50}$ values, a sample incubated with pure DMSO served as a control for $0 \%$ inhibition, whereas a sample without the addition of ATP served as a control for $100 \%$ inhibition. The $\mathrm{IC}_{50}$ value of TBB was determined using nine different concentrations in appropriate intervals ranging from $100 \mathrm{pM}$ to $10 \mu \mathrm{M}$. For silmitasertib, dose-response data using nine concentrations in appropriate intervals ranging from $10 \mathrm{pM}$ to $1 \mu \mathrm{M}$ were analyzed for $\mathrm{IC}_{50}$ determination.

\section{Influence of $\mathrm{NaCl}$ on the enzymatic activity of surface displayed CK2 $\alpha$ and CK2 holoenzyme}

For this purpose, enzymatic activities of whole cell either displaying CK $2 \alpha$ or $\mathrm{CK} 2 \alpha$ and $\mathrm{CK} 2 \beta$ were determined as described above for $\mathrm{IC}_{50}$ values with slight modifications. Briefly, $80 \mu \mathrm{L}$ of the bacteria suspension in kinase buffer (50 mM Tris/ $\mathrm{HCl}, \mathrm{pH} 7.5,20 \mathrm{mM} \mathrm{MgCl}_{2}$ and $1 \mathrm{mM} \mathrm{DTT}$ ) with eight different concentrations of $\mathrm{NaCl}$ concentrations ranging from 0 to $300 \mathrm{mM}$ were incubated at $30^{\circ} \mathrm{C}$ and $400 \mathrm{rpm}$ for $15 \mathrm{~min}$. CK2-reactions were initiated by the addition of $120 \mu \mathrm{L}$ of assay buffer $(25 \mathrm{mM}$ Tris/ $\mathrm{HCl}$, $\mathrm{pH}$ 8.5, $20 \mathrm{mM} \mathrm{MgCl}_{2}, 1 \mathrm{mM}$ DTT, $167 \mu \mathrm{M}$ substrate peptide RRRDDDSDDD and $1 \mathrm{mM}$ ATP) having the identical concentration of $\mathrm{NaCl}$ as the sample with the kinase buffer they were added to. Final concentrations in a total volume of $200 \mu \mathrm{L}$ were $100 \mu \mathrm{M}$ for the substrate peptide and $600 \mu \mathrm{M}$ for ATP with a final cell density of $\mathrm{OD}_{578}=2$, which corresponded to $\sim 1.7 \times 10^{8}$ cells $/ \mathrm{mL}$. For each sample enzymatic reaction was run for $60 \mathrm{~min}$ at $30^{\circ} \mathrm{C}$ and $400 \mathrm{rpm}$. CK2 displaying bacterial cells were removed by centrifugation at $3,850 \times g$ for $10 \mathrm{~min}$ at $4^{\circ} \mathrm{C}$ and the supernatant was transferred to a well of a microplate (96 well format). There $12.5 \mathrm{mM}$ EDTA was added at $4^{\circ} \mathrm{C}$ to remove any free divalent cations and definitely stop the enzymatic reaction. Subsequently phosphorylation of the substrate peptide was analyzed by capillary electrophoresis as described above.

\section{Results}

Autodisplay of CK2 subunits $\alpha$ and $\beta$

For surface display of $C K 2 \alpha$ and $C K 2 \beta$, two artificial fusion genes were constructed, each of which contained sequences coding for essential domains for autodisplay and an open reading frame for $\mathrm{CK} 2 \alpha$ or $\mathrm{CK} 2 \beta$, respectively. The resulting fusion genes encoded a fusion protein with the following domain architecture: An $N$-terminal signal peptide, the passenger domain (either CK $2 \alpha$ or CK2 $\beta$ subunit), a linker sequence and the $\beta$-barrel domain that anchors the surface-exposed passenger in the outer membrane of Gram-negative $E$. coli. For autodisplay of both CK2 subunits two individual fusion proteins were produced and anchored in the outer membrane: CK $2 \alpha$-AT containing CK $2 \alpha$ subunit as the passenger domain (Figure 1a) and CK2 $\beta$-AT, containing CK2 $\beta$ subunit as the passenger domain (Figure $1 \mathrm{~b}$ ). Protein production was facilitated in both cases by using plasmids with the strong T7 promoter for IPTG-inducible expression in E. coli via a T7 RNA polymerase gene under UVlac5 control. E. coli strain BL21(DE3) was used as a host for autodisplay due to its deficiency of outer membrane protease OmpT.

The absence of OmpT avoids the cleavage of the autodisplayed protein on the cell surface. E. coli BL21(DE3) was transformed with either expression plasmid pCK $2 \alpha$ (encoding CK $2 \alpha-\mathrm{AT}$ ) or pCK2 $\beta$ (encoding CK $2 \beta-\mathrm{AT}$ ) or with both plasmids. For maintaining both plasmids in a single cell, bacteria were grown in such case with the two antibiotics carbenicillin and kanamycin. Following growth and induction of protein formation, the individual outer membrane-containing fraction of each strain was analyzed by SDS-PAGE.

In all samples, a strong expression of the autotransporter fusion proteins could be detected when comparing the samples of the plasmid containing strains with that of the host strain outer membrane fraction (Figure 2). In samples of $E$. coli BL21(DE3) pCK2 $\alpha$, the expected molecular weight of $95 \mathrm{kDa}$ for CK2 $\alpha$-AT was in agreement with the appearance of a protein at an apparent molecular weight in this range (Figure 2, line 5). The same is true for expression of CK2 $\beta$-AT in E. coli BL21(DE3) pCK2 $\beta$, where the apparent molecular weight of the extra band corresponded to CK2 $\beta$-AT's predicted size of $74 \mathrm{kDa}$ (Figure 2, line 7). It appeared from the density of the CK2 fusion protein bands, that expression of CK2 $\beta-A T$ 


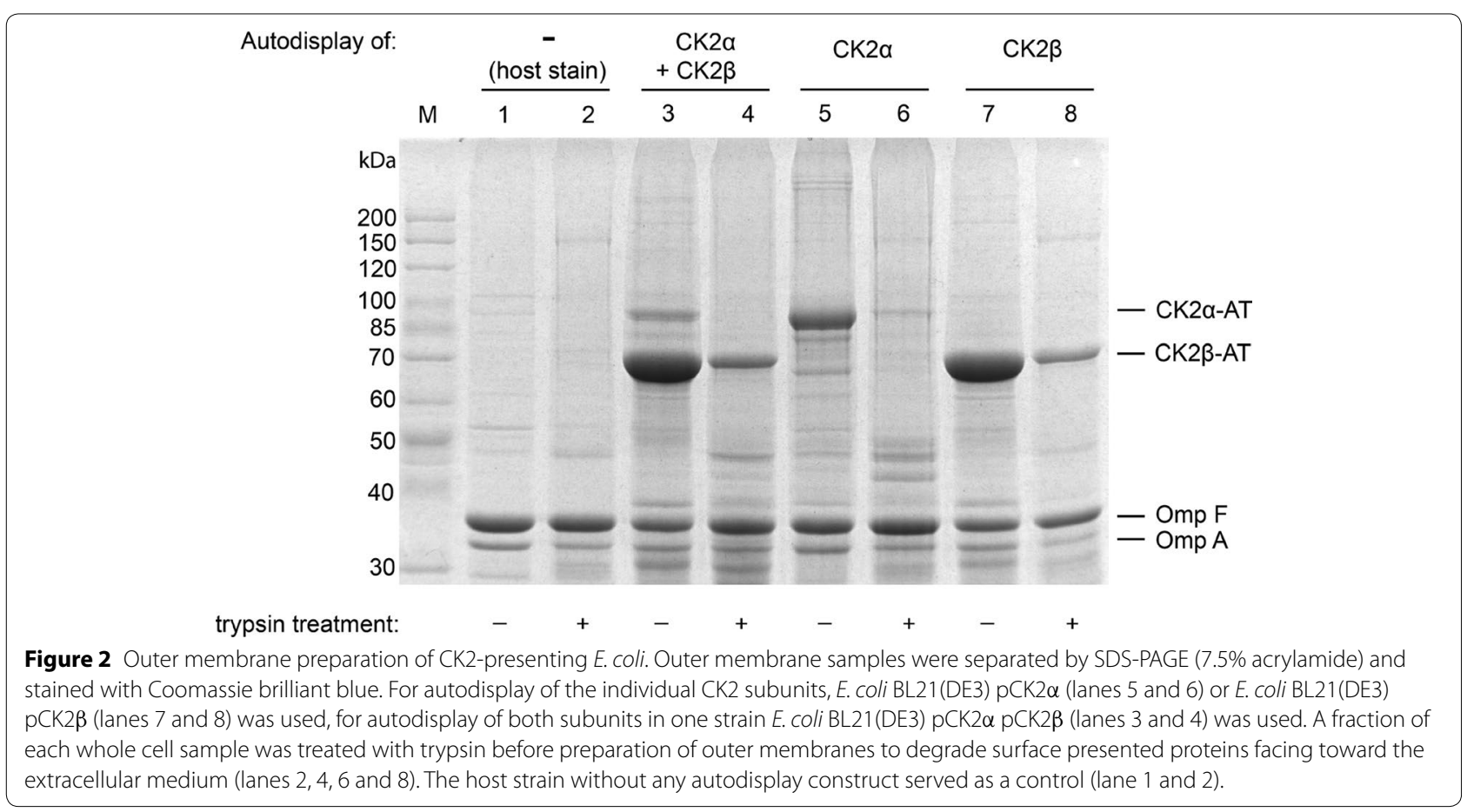

was much more efficient than expression of CK2 $\alpha$-AT. This could have been due to several reasons. First of all, because both human sequences were not codon optimized for expression in $E$. coli, the presence of rare codons in $C K \alpha$ could interfere with its expression, whereas such effect could be less severe in CK2 $\beta$. Second, it could have been the result of a gene dosage effect, namely that the copy number of the plasmid encoding $\mathrm{Ck} 2 \alpha$, with the pET vector backbone (ColE1 origin of replication) was less than the copy number of the plasmid encoding CK2 $\beta$, based on the pCOLADuet backbone (ColA origin). Both vectors, however, were described to be medium copy number plasmids with about 15-40 copies per cell [31]. At this point, it seems unlikely, that Coomassie staining of CK $2 \alpha$ was less efficient than staining of CK $2 \beta$, because such a difference in Coommassie staining of both subunits was not observed when the recombinant human CK2 holoenzyme was analyzed by SDS-PAGE [32].

Following the successful individual expression of both CK2 subunits, E. coli BL21(DE3) was transformed with both plasmids, pCK $2 \alpha$ and pCK2 $\beta$ to enable co-expression and autodisplay of CK $2 \alpha-\mathrm{AT}$ and CK $2 \beta$-AT in a single strain. Analysis of outer membrane isolates indicated that while the expression level of CK2 $\beta$-AT was identical to that in the strain displaying CK2 $\beta$-AT alone, a further decrease in expression of CK $2 \alpha$-AT was observed in comparison to the expression of CK2 $\alpha$-AT alone (Figure 2, line 3). This could be a first indication, that indeed codon usage could account for this effect.
A presence of the fusion protein in the outer membrane fraction of E. coli alone does not prove surface exposure of its passenger domain. The addition of the protease trypsin to an E. coli suspension is a commonly used tool to examine passenger accessibility from the outside [33, 34]. Trypsin is considered too large for crossing the outer membrane. Thus, if the passenger domain is not exposed to the surface, trypsin is not able to access the fusion protein and it stays intact. In case the passenger domain is directed towards the surface, the fusion protein can be digested and its molecular weight will be reduced. On the other hand, if the integrity of the outer membrane was infringed, the protease would enter the periplasm and the fusion protein would be degraded independent from its orientation. In the latter case however, OmpA would be degraded as well due to its $C$ terminal extension which is covalently linked to the murein layer of the cell wall. For this reason, appearance of full-length OmpA in an outer membrane fraction after trypsin treatment of whole cells is an internal control for the integrity of the outer membrane and hence a prerequisite for the validity of the experiment. In conclusion, if full-length OmpA is present and the full-length fusion protein is degraded, there is strong evidence for surface exposure of the passenger domain. Trypsin treatment of whole cells displaying either CK $2 \alpha$, or CK $2 \beta$ or both subunits resulted in a substantial decrease of full-length autodisplay fusion proteins in all cases (Figure 2, lines 4, 6 and 8). Due to the high expression level of CK2 $\beta$-AT, it 
was not degraded completely after trypsin treatment of whole cells and a faint CK2 $\beta$-AT band is still visible after SDS-PAGE (Figure 2, lane 8). In contrast, the modestly expressed CK $2 \alpha$-AT could be hydrolyzed almost completely by trypsin (Figure 2, lane 6). The outer membrane integrity could be ensured in all samples: the marker protein OmpA appeared in its full-length form and was not affected by trypsin treatment. These results clearly indicate the surface-exposure of both CK2 subunits, when separately expressed or when simultaneously expressed in E. coli BL21(DE3).

\section{Interaction of CK2 $\alpha$ and CK2 $\beta$ on the cell surface}

The $\beta$-barrel domain anchors the autotransporter fusion protein in the outer membrane and its motility within the plane of membrane has been shown to enable passenger-driven clustering of multimeric proteins [7]. Due to the strong affinity between both CK2 subunits in vitro $\left(\mathrm{K}_{\mathrm{D}}=4 \mathrm{nM}\right)$ [2], CK2 subunits assemble spontaneously from individually purified $C K 2 \alpha$ and $C K 2 \beta$. Based on this scenario, surface-presented CK $2 \alpha$ and CK2 $\beta$ could interact on the cell surface to form a functional holoenzyme. The anticipated interaction of both displayed CK2 subunits was investigated by a co-immunoprecipitation approach. Therefore, outer membrane preparation of CK2 expressing E. coli BL21(DE3) strains were precipitated with a monoclonal anti-CK $2 \alpha$ antibody (1A5) [28] and analyzed for co-precipitated CK $2 \beta$-AT. An interaction between $C K 2 \alpha$ - and $C K 2 \beta$-subunit was found by the occurrence of CK2 $\beta$-AT in such precipitates in SDSPAGE and Western blot immunostained with an antiCK2 $\beta$ antiserum [27] (Figure 3).

CK $2 \alpha$-AT precipitation was shown in all membrane samples of CK $2 \alpha$-AT expressing strains by the appearance of a $95 \mathrm{kDa}$ protein band (Figure 3a, lanes 3, 5). Precipitation after co-expression of $\mathrm{CK} 2 \alpha$ and $\mathrm{CK} 2 \beta$ yielded a clear band on a SDS-PAGE gel at the expected molecular weight of the CK2 $\beta$-AT protein (74 kDa) (Figure 3a, lane 3). Moreover, in the corresponding Western blot the $74 \mathrm{kDa}$ band was labeled by the anti CK2 $\beta$ antiserum, confirming that indeed CK2 $\beta$ was co-precipitated with CK $2 \alpha$ (Figure 3b, lane 3). As can be seen in lanes 2 of Figure $3 \mathrm{a}$ and $\mathrm{b}, \mathrm{CK} 2 \beta$ was not completely co-precipitated with the anti $C K 2 \alpha$ beads, and hence still present in the supernatant. This can be due to the much stronger expression of CK2 $\beta$ in comparison to CK $2 \alpha$ on the cell surface (Figure 2, lane 3 ), which is supposed to result in an excess of CK2 $2 \beta$ and in consequence, in free CK2 $\beta$ molecules on the cell surface in addition to those interacting with $\mathrm{CK} 2 \alpha$.

The corresponding controls indicated that in the outer membrane fractions containing only CK2 $2 \beta$-AT or no CK2 subunit at all, no $74 \mathrm{kDa}$ protein was precipitated by

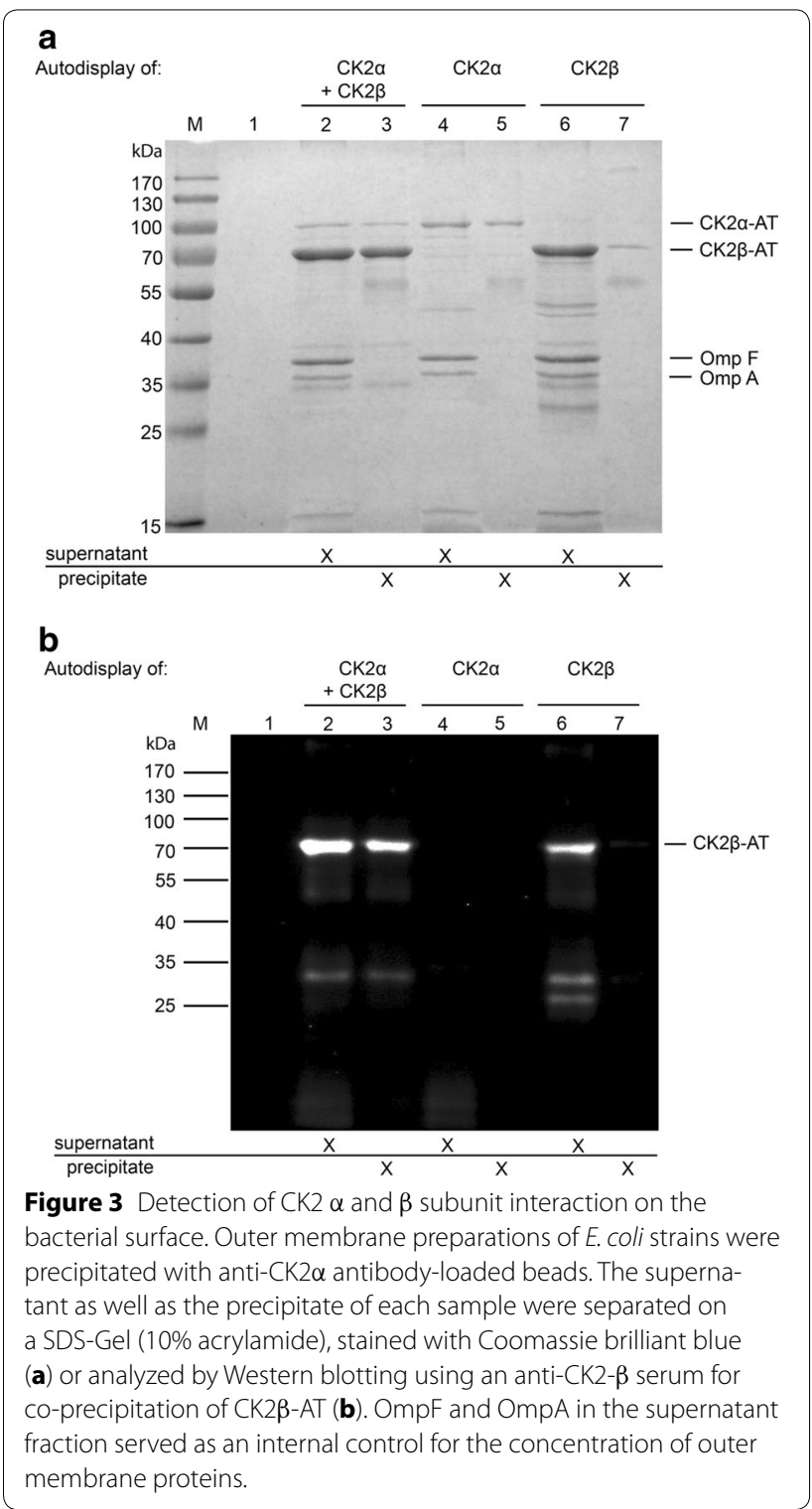

the anti CK $2 \alpha$ antibody (Figure 3a, lanes 5, 7). Application of the identical precipitation protocol to outer membrane fractions of CK2 $\beta$-displaying strain resulted in a tiny amount of CK2 $\beta$-AT (Figure 3a, lane 7), probably caused by an unspecific interaction of CK2 $\beta$-AT with the antibody-coated beads. Due to the very small quantity of this precipitate, it does not contribute significantly to the huge amount of precipitate found in samples with CK $2 \alpha-\mathrm{AT}$ and CK2 $\beta$-AT, and can be disregarded. In the Western blot of the controls, these findings were confirmed: just a faint band was detected when trying to precipitate the CK2 $\beta$-containing sample (Figure $3 \mathrm{~b}$, lane 7). In samples using antibody $1 \mathrm{~A} 5$ alone (Figure $3 \mathrm{a}, \mathrm{b}$, lanes 1), and without autodisplay of CK2 $\beta$ (Figure $3 a, b$, lane 4) no protein band of $74 \mathrm{kDa}$ was detectable after 
co-precipitation, excluding the possibility of a mistaken identity of the CK2 $\beta$-AT band. As a result, the co-precipitation of CK $2 \beta$-AT and CK $2 \alpha$-AT showed an affinitybased complex formation of $\alpha$ - and $\beta$-subunit on the cell surface, which was a first indication for a possible correct folding and assembly of the CK2 holoenzyme.

\section{Kinase activity of $E$. coli cells displaying CK2 $\alpha$ and $\mathrm{CK} 2 \alpha+\mathrm{CK} 2 \beta$}

The phosphotransferase activity of E. coli BL21(DE3) strains, displaying either CK2 $\alpha$ and CK2 $\beta$ alone or in combination, was examined by a commonly used radiometric filter binding assay with the standard CK2-specific substrate peptide RRRDDDSDDD (Figure 4).

No kinase activity could be detected for the host strain E. coli BL21(DE3) $(1,264 \mathrm{cpm})$ or for the strain that displayed CK2's catalytically inactive $\beta$ domain alone $(1,264 \mathrm{cpm})$. In contrast, autodisplay of CK2 $\alpha$ results in a phosphorylation of the peptide RRRDDDSDDD with a value of 7,638 cpm. The co-expression strain, presenting both CK2 subunits, yielded an even higher activity $(9,802 \mathrm{cpm})$, although the expression level of the catalytic CK $2 \alpha-\mathrm{AT}$ was reduced by a factor of 5 compared to a separate expression (Figure 2, lanes 3,5 ). If the activity is normalized to the expression level, autodisplay of both subunits yielded a $>5$-fold increase over the activity of the CK $2 \alpha$-presenting strain alone. This takes into consideration that reduction of the expression level of the catalytic subunit $\mathrm{CK} \alpha$, will lead to reduction of available active sites to the same extent. Obviously, autodisplay of CK2 $\beta$ along with CK2 $\alpha$ stimulates CK2 activity, which was a further hint on a possible functional subunit interaction at the E. coli cell surface. In order to exclude any false-positive activity data in the whole-cell assay, the $E$. coli strain displaying both subunits was treated with the selective CK2 inhibitor 4,5,6,7-tetrabromobenzotriazole (TBB). In a concentration of $10 \mu \mathrm{M}$, TBB almost completely blocked CK2 activity (1,809 cpm), thus confirming that in fact the activity of surface-displayed CK2 was responsible for peptide phosphorylation. However, the high standard deviation in the radiometric whole-cell assay makes this assay format inappropriate for routine inhibitor screenings. To eliminate the unfavorable deviations, the radiometric filtration binding assay was replaced by a recently developed CK2 assay based on capillary electrophoresis (CE) [29]. Originally, this assay was described as an inhibition test for purified CK2, but the use of $E$. coli cells displaying CK2 $\alpha$ and CK2 $2 \beta$ also resulted in a conversion of the substrate peptide RRRDDDSDDD in the CE-assay. A substrate phosphorylation of about $10-15 \%$ was achieved after $60 \mathrm{~min}$ by a cell suspension with an $\mathrm{OD}_{578}=2\left(1.72 \times 10^{8}\right.$ cells $\left./ \mathrm{mL}\right)$ in the assay volume of $200 \mu \mathrm{L}$. With these settings, an initial CK2 reaction velocity $\left(\mathrm{v}_{\mathrm{i}}\right)$ could be recorded in all

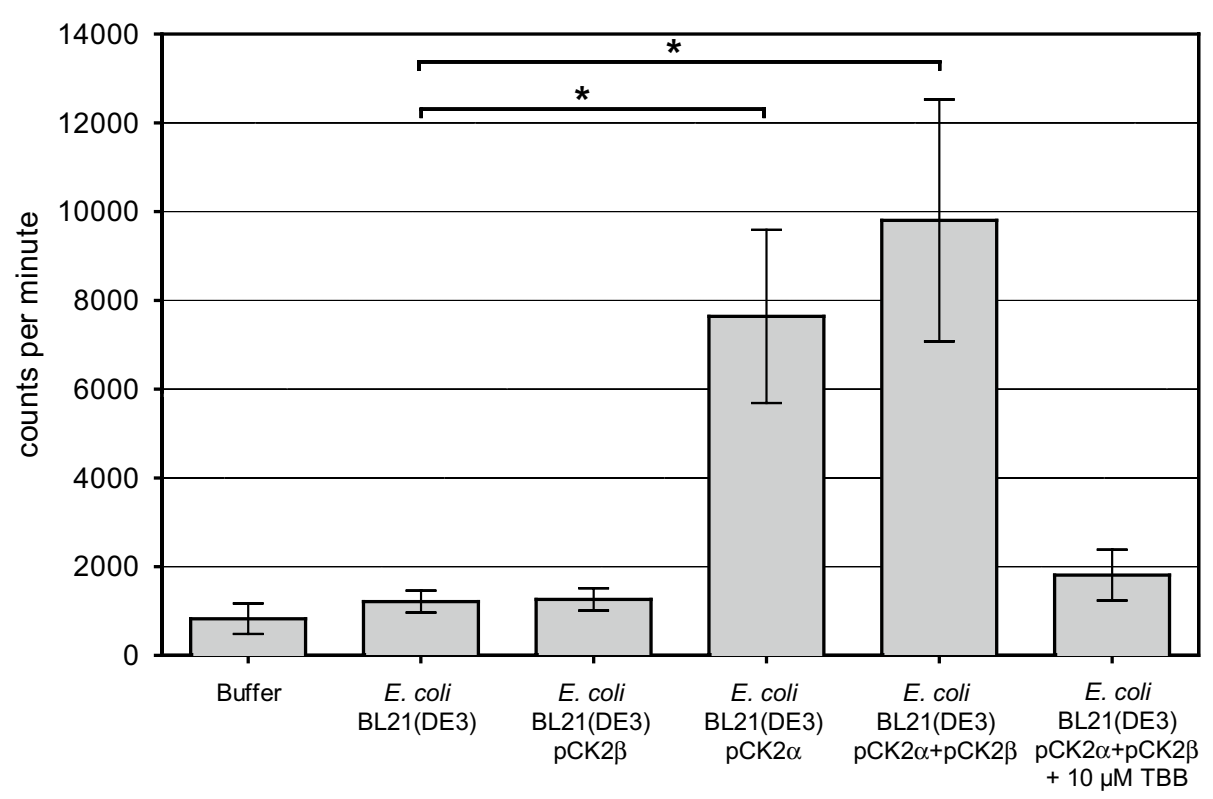

Figure 4 Radiometric CK2 assay using CK2-presenting E. coli. The amount of transferred ${ }^{32} \mathrm{P}$ from $\gamma$ - $\left[{ }^{32} \mathrm{P}\right]$-ATP onto the synthetic substrate peptide RRRDDDSDDD was quantified in counts per minute (cpm). Reactions were catalyzed by surface display of CK2 $\beta$ [E. coli BL21(DE3) pCK2 $\beta$ ], CK2 $\alpha$ [E. coli BL21(DE3) pCK2 $\alpha$ ] and both, the $\alpha$ - and $\beta$-subunit of CK2 [E. coli BL21(DE3) pCK2 $\alpha$ pCK2 $\beta$ ]. Samples with the host strain or completely without cells were used as controls, having no CK2 kinase activity. E. coli BL21(DE3) pCK2 $\alpha$ pCK2 $\beta$ was treated with the CK2 inhibitor TBB in a concentration of $10 \mu \mathrm{M}$ prior to reaction start. The histograms display mean values ( \pm standard deviation, $n=3,{ }^{*} p<0.005$ ). 
following experiments using surface-displayed CK2. In contrast to the radiometric assay, the quantification of CK2 activity resulted in a considerably lower standard deviation.

\section{CK2 holoenzyme formation on the cell surface}

Interaction of CK $2 \alpha-\mathrm{AT}$ and CK2 $\beta$-AT on the cell surface alone is not sufficient to prove heterotetrameric CK2 holoenzyme formation. Although CK $2 \alpha / C K 2 \beta$ dimers have not been observed yet, and heterotetramer formation is generally considered to proceed by formation of a CK2 $\beta$ dimer, which subsequently collects two $\alpha$-subunits to form the heterotetramer, further experimental evidence was required in order to validate that this can happen on the cell surface as well. At this point it appears worth mentioning, that the linker domain between the CK2 $\alpha$ and $\beta$ subunit passengers and the membrane anchored $\beta$-barrel domain (Figure 1a, b), comprised 160 amino acid, which were shown before to provide sufficient flexibility to allow passenger domains to interact e.g. in opposite directions without hampering enzymatic activity [9, 11]. From the number of amino acids and the flexibility of the linker domain, it was suggested, that it would not interfere with the critical $\mathrm{N}$ terminus of the $\alpha$-subunit and in addition, the complex growth medium used to cultivate the $E$. coli cells, which contained $5 \mathrm{~g} / \mathrm{L}$ yeast extract, provided sufficient zinc ions, which are required for the initial dimerization of the $\beta$-subunits.

For further experimental evidence, the $\mathrm{NaCl}$ dependency of surface displayed CK2 $\alpha$ and surface co-displayed CK $2 \alpha+$ CK2 $\beta$ were investigated. It has been known for a long time, that the enzymatic activity of human CK2 is dependent on the $\mathrm{NaCl}$ concentration in the assay. [3538]. Interestingly, the influence of $\mathrm{NaCl}$ is different in case the enzymatic activity of the holoenzyme is determined, in comparison to the activity of the catalytic $\alpha$-subunit alone. Whereas the $\alpha$-subunit is more and more inhibited by increasing concentrations of $\mathrm{NaCl}$, finally leading to an almost completely inactive enzyme, the holoenzyme is activated by increasing concentrations of $\mathrm{NaCl}$ [39]. Therefore we measured the enzymatic activity of cells displaying either the $\alpha$-subunit alone, or the $\alpha$-subunit together with the $\beta$-subunit in the CE-assay with the substrate peptide RRRDDDSDDD in the presence of different concentrations of $\mathrm{NaCl}$, ranging from 0 to $300 \mathrm{mM}$.

As shown in Figure 5, a NaCl concentration of $25 \mathrm{mM}$ strongly decreased the enzymatic activity of cells displaying only $\mathrm{CK} 2 \alpha$. Increasing concentrations of $\mathrm{NaCl}$ lead to further inhibition of $\mathrm{Ck} 2 \alpha$ ending up with an almost negligible enzymatic activity at a $\mathrm{NaCl}$ concentration of $300 \mathrm{mM}$. In contrast, increasing concentrations of $\mathrm{NaCl}$ activated the enzymatic activity of cells displaying $\mathrm{Ck} 2 \alpha$ together with CK2 $\beta$ with the highest activity obtained at

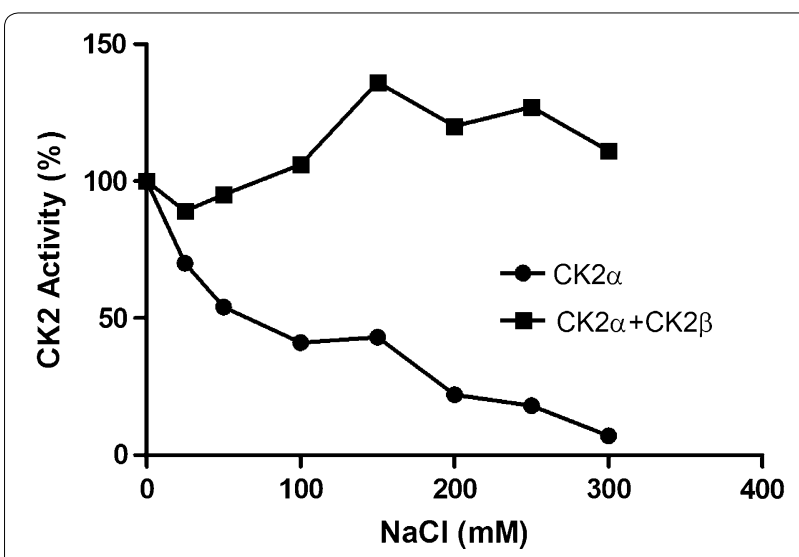

Figure 5 Influence of $\mathrm{NaCl}$ on surface displayed human $\mathrm{CK} 2 \alpha$ (filled circle) and surface displayed human CK2 $\alpha+$ CK2 $\beta$ (filled square). Increasing concentrations of $\mathrm{NaCl}$ ranging from 0 to $300 \mathrm{mM}$ were applied, and the kinase activity of cells either displaying CK2 $\alpha$ or CK2 $\alpha+$ CK2 $\beta$ were determined by the CE assay. The substrate peptide (RRRDDDSDDD) concentration was $100 \mu \mathrm{M}$ and the ATPconcentration was $600 \mu \mathrm{M}$. Activity was measured for $60 \mathrm{~min}$ at $30^{\circ} \mathrm{C}$ with cells of an $\mathrm{OD}_{578}=2$, which corresponds to $1.72 \times 10^{8}$ cells $/ \mathrm{mL}$. Samples without $\mathrm{NaCl}$ were set to $100 \%$ activity.

a concentration of $150 \mathrm{mM}$. Further increase of $\mathrm{NaCl}$ to concentrations of 200 or $300 \mathrm{mM}$ still activated the enzymatic activity of these cells, but not to the same extent as observed at $150 \mathrm{mM}$. The curves of activity that were obtained with the surface displayed CK2 $\alpha$ and with surface displayed CK $2 \alpha+$ CK2 $\beta$ were almost completely congruent with those obtained earlier for the free CK $2 \alpha$ subunit and CK2 holoenzyme [39]. Consequently, it was concluded that co-expression of CK2 $\alpha$ and CK2 $\beta$ on the surface of $E$. coli must have led to the formation of an active CK2 holoenzyme.

\section{Inhibitor testing}

The easy access to the drug target CK2 by autodisplay enables the implementation of an assay without the need to purify the CK2 holoenzyme. Based on this idea, a dose-dependent inhibition of autodisplayed CK2, by TBB, a known inhibitor with a benzotriazole scaffold (4,5,6,7-tetrabromobenzotriazole) was determined in the CE assay with the substrate peptide RRRDDDSDDD. The concentrations of the inhibitor applied range from $100 \mathrm{pM}$ to $10 \mu \mathrm{M}$ and resulting enzymatic activity lead to the determination of an $\mathrm{IC}_{50}$ value of $0.05 \mu \mathrm{M}$ of TBB (Figure 6a).

This $\mathrm{IC}_{50}$ value is in agreement with the value of $0.06 \mu \mathrm{M}$, obtained in a CK2-assay with purified free CK2 holoenzyme [32]. In addition, the $\mathrm{IC}_{50}$ value of silmitasertib (5-(3-chloro-phenylamino)benzo[c] [2, 6]naphthyridine-8-carboxylic acid, CX4945), one of the most potent CK2 inhibitors known, and at present in clinical trials, 

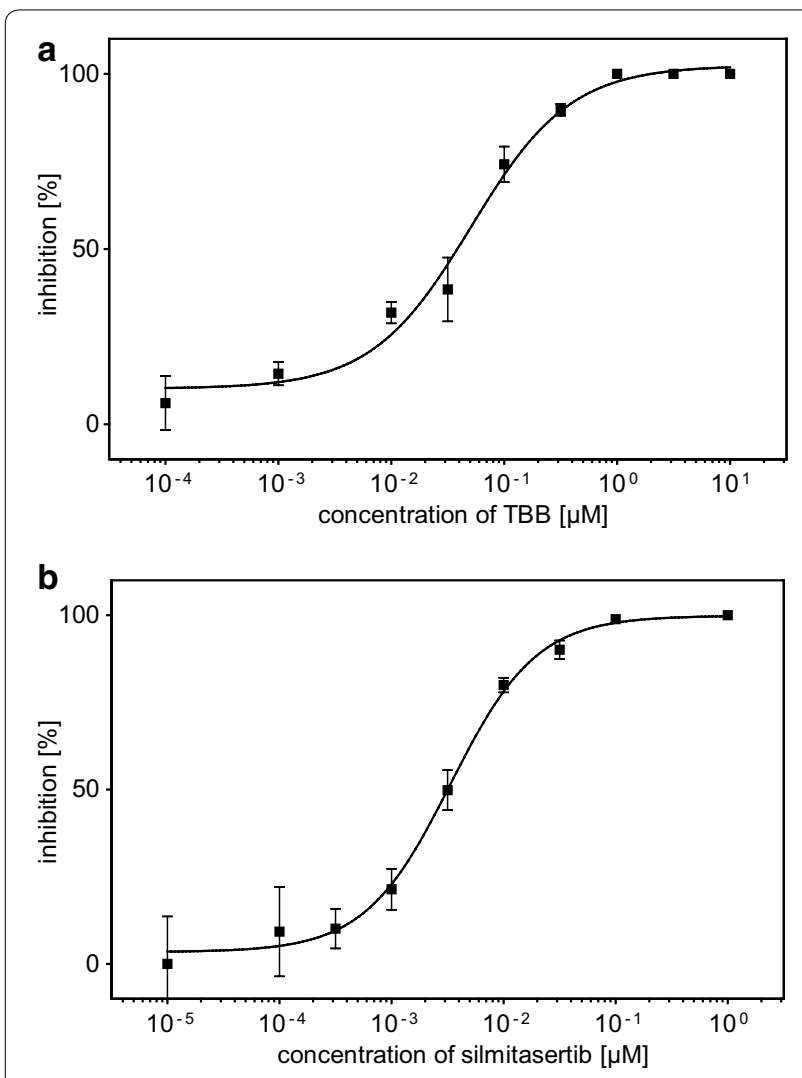

Figure 6 Dose-dependent inhibition of surface-displayed CK2 measured by the CE-assay. E. coli BL21(DE3) pCK2 $\alpha$ pCK2 $\beta$ was incubated with different concentrations of a TBB (100 pM-10 $\mu \mathrm{M})$ or $\mathbf{b}$ silmitasertib (10 pM-1 $\mu \mathrm{M})$ for 10 min before the reaction was started. CK2 activity was determined by capillary electrophoretic quantification of product rate. The fractional inhibition values were calculated in respect to an uninhibited sample and are given as mean values ( \pm standard deviation, $n=3$ ). The $I_{50}$ values were obtained by fitting the dose-dependent inhibition data to a sigmoidal fourparameter logistic equation.

was also assessed with the surface-displayed CK2 holoenzyme. The resulting $\mathrm{IC}_{50}$ of $3.3 \mathrm{nM}$ (Figure $5 \mathrm{~b}$ ) is in line with the $\mathrm{IC}_{50}$ value of $3.7 \mathrm{nM}$ that was published using purified CK2 holoenzyme in the CE-assay [32]. Moreover, it is in good agreement with the $\mathrm{IC}_{50}$ value of $1 \mathrm{nM}$ that Pierre et al. [21] originally reported using a radiometric assay with a slightly different ATP concentration. The reliable quantification of in vitro inhibition and the unity of both $\mathrm{IC}_{50}$ values with published data obtained with the purified enzyme indicate suitability of surfacedisplayed CK2 for screening and characterization of CK2 inhibitors.

\section{Discussion}

The functional autodisplay of pharmaceutically interesting target proteins on the surface of $E$. coli provides an alternative to protein purification and appears to be a powerful tool for enzyme assays. It proved especially advantageous, if the target protein is unstable in its purified form or builds inclusion bodies upon intracellular expression. The autotransporter secretion machinery, which is used by autodisplay, keeps the fusion protein in an unfolded state until it is being translocated. This feature obviously helps avoiding (intracellular) target protein inclusion bodies. Heterologous expression of human hyaluronidase 1 (Hyal-1) in E. coli, for example, was shown to form inclusion bodies resulting in an inactive enzyme that can exclusively be found in the insoluble E. coli cell fraction. Even optimized refolding yielded extremely low hyaluronidase activity [40]. The production of hyaluronidases in eukaryotic expression systems provided low yields, representing a bottleneck in early drug discovery. Autodisplay of human hyaluronidase $\mathrm{hPH}-20$ circumvents the forming of inclusion bodies and results in surface-displayed, active enzyme that can be used for inhibitor screenings [41]. The concept of a quick and cost-effective surface display of target enzymes was applied to protein kinase CK2.

In this report we describe the successful surface-display of active human CK2 on the cell surface of E. coli by autodisplay. The fusion proteins CK $2 \alpha-\mathrm{AT}$ and CK $2 \beta$-AT were expressed together or individually in $E$. coli, translocated to the cell surface and anchored in the outer membrane. In whole cell samples, trypsin was able to access and degrade the fusion proteins, confirming their surface exposure. Not only kinase activity of whole E. coli cells after autodisplay of the catalytically active subunits CK $2 \alpha$ was detectable, moreover, combined autodisplay of CK $2 \alpha$ and CK2 $\beta$ lead to the formation of an active holoenzyme at the cell surface as it was indicated by its $\mathrm{NaCl}$ activation. The important role of CK $2 \beta$ for stability and protection of CK $2 \alpha$ against denaturing agents and proteolytic degradation was reported for the reconstituted purified recombinant holoenzyme by Meggio et al. [42]. Similarly, the activity data presented here show that CK2 $\beta$-AT helps stabilizing CK $2 \alpha-\mathrm{AT}$ in an active conformation. A formation of CK $2 \alpha / \beta$ complexes found in co-precipitation experiments mechanistically supported the possible assembly of a holoenzyme-like CK2 complex. Although passenger-driven assembly of a quaternary complex at the cell surface has been demonstrated for homomeric enzymes, autodisplay of a fully functional heteromeric enzyme has been reported in this study for the first time.

A major disadvantage in the autodisplay of $C K 2$, which requires further improvement is the different expression levels obtained for CK $2 \alpha$ and CK2 $2 \beta$. This difference in expression even increased when both subunit were co-expressed on the surface of a single cell. Because the promoters used in both expression plasmids were identical, and the copy number derived from 
the origins of replication in both plasmids, either ColE1 or ColA were reported to be (mostly) identical (15-40 copies per cell), a different effect needs to be the reason. We analyzed the codon usage in the human sequences of CK $2 \alpha$ and CK2 $\beta$ as applied here for expression in E. coli as fusion proteins with the autotransporter domains. The CK2 $\beta$ sequence contained 12 codons out of 215 , which are rarely used in $E$. coli, with only three codons for tRNAs available equal or less than $3 \%$. In contrast, the CK2 $\alpha$ sequence contained 30 codons out of 391 , which are rarely used in $E$. coli, with nine codons for tRNAs available equal or less than $3 \%$. Moreover, six of the human codons rarely used in $E$. coli are present in $\mathrm{CK} \alpha$ within a single stripe encoding amino acids residues 168-173. This could be a hint that indeed the different codon usage in both human subunits accounts for the observed differences in expression of surface displayed CK $2 \alpha$ and CK2 $2 \beta$. The next step will be to optimize the codon usage for both subunits with respect to the host organism E. coli, and find out whether this will lead to more equal expression. In addition it should lead to an increase in the activity of whole cells displaying CK $2 \alpha$, but of cells displaying CK $2 \alpha+$ CK $2 \beta$, as well. As indicated in the co-precipitation experiments (Figure $3 a, b$, lanes 2), at current, there appears to be a surplus of CK $2 \beta$ subunits, which are unable to gather CK $2 \alpha$ binding partners.

We used the different $\mathrm{NaCl}$ dependency of CK2 $\alpha$ and CK2 holoenzyme [39] in order to elucidate holoenzyme formation by surface displayed $\alpha$ - and $\beta$-subunits. The phosphotransferase activity of cells displaying CK $2 \alpha$ was inhibited by increasing concentrations of $\mathrm{NaCl}$, whereas the activity of cells displaying $\mathrm{CK} \alpha+\mathrm{CK} 2 \beta$ were activated with increasing concentrations of $\mathrm{NaCl}$, as it was reported before for free CK2 $\alpha$ and CK2 holoenzyme [39] and thus indicating the formation of functional CK2 holoenzyme on the cell surface. Moreover the curves obtained in both cases, i.e. catalytic activity versus $\mathrm{NaCl}$ concentration were almost identical with those obtained with the free $\alpha$-subunit and the free holoenzyme, Calmodulin is a substrate protein that has been reported to be preferably phosphorylated by the $\alpha$-subunit and the regulatory $\beta$-subunit in the holoenzyme almost completely inhibits its phosphorylation. This inhibitory effect may be overcome by polybasic peptides [42]. But because on one hand, this is a rather gradual effect and calmodulin is quite expensive, and on the other hand, the results obtained with the $\mathrm{NaCl}$ dependency of the catalytic activities were such unambiguous, we abstained from this approach. Whereas the homodimerization or homomultimerization of enzyme subunits expressed at the cell surface of $E$. coli has been reported earlier [8, 9, 16, 43, 44], this is the first report on the functional surface display of a heterotetrameric enzyme by displaying the subunits individually.

CK2 activity can easily be produced with the presented autodisplay system just-in-time for inhibition screenings or for kinetic studies of potential CK2 inhibitors. The often complex and time-consuming purification process can be avoided and "fresh" enzyme activity is available within 1 day, while storage artifacts like partially inactive or degraded enzyme species can be massively reduced. During intracellular recombinant expression and purification of CK2 $\alpha$ for example, a fraction of the protein loses a $\mathrm{C}$ terminal domain of 54 amino acids due to spontaneous degradation [45]. Although the activity and the interaction of this truncated CK2 $\alpha$ with CK2 $\beta$ remain unaltered, the degradation might affect some features other than kinase activity and hence should be minimized as much as possible $[46,47]$. When CK2 $\alpha$ is produced as an autodisplay-passenger, its $C$ terminus is obviously protected from the described degradation and the full-length autodisplay fusion protein CK2 $\alpha$-AT was detected in SDS-PAGE. This stabilization of sensitive proteins, which require a solid support or a membrane environment for their functional integrity, is a known general benefit of autodisplay. In similar cases this was shown previously, e.g. for cytochrome P450 enzymes, which need a lipophilic surrounding for their enzymatic activity. Autodisplay of CYP106A2 and CYP3A4 yielded whole cell biocatalysts converting $\mathrm{P} 450$-specific substrates $[10,25]$.

There are a few important factors to consider when using a whole-cell biocatalyst instead of a purified enzyme. First, the applied activity assay needs to tolerate living E. coli organisms and the assay conditions $(\mathrm{pH}$, solvents, etc.) must be chosen carefully so that the cellular integrity of $E$. coli is not disrupted. Bacterial cells remained intact during the assays as described, but in the radiometric kinase assay, the whole-cell approach may have contributed to the high standard deviation. The presence of $E$. coli in the CK2 reaction indeed showed an additional peak during $\mathrm{CE}$ analysis. However, the additional peak did not interfere with product quantification. Second, the assay substrate(s) and products may not be taken up actively and may not be metabolized by E. coli. The CK2 substrate peptide RRRDDDSDDD (including its phosphorylated form) is considered too large to cross the outer membrane of $E$. coli and in fact, we could not detect a decrease of substrate peptide concentration upon incubation with $E$. coli for $>1 \mathrm{~h}$. The impermeability of the cell envelope for the substrate peptide is another proof for the surface exposure of CK2, since its detected phosphorylation must be catalyzed by the surface-displayed CK2. An uptake of the CK2 co-substrate ATP cannot be fully excluded, since the outer membrane porin OmpF allows 
the passive diffusion of small $(<600-700 \mathrm{Da})$ hydrophilic substances. In our experiments, however, surfacepresented CK2 was still active $>2 \mathrm{~h}$ after reaction start. If there is a decrease of ATP concentration caused by an uptake by the bacteria, it is in a very small order of magnitude. A recent report supports the notion that an uptake of ATP by $E$. coli even with minimum medium is very slow [48]. Third, due to the complex nature of a whole-cell biocatalyst, the concentration of active protein cannot be determined exactly. It must be deduced from SDS-PAGE of whole cell lysates or outer membrane fractions and then be compared to a stably expressed internal standard, like OmpA. At this point it needs to be taken into consideration, that the anchoring of the enzyme in the outer membrane by the $\beta$-barrel, which in consequence means, that its $C$ terminus is covalently linked to the $\mathrm{N}$ terminus of the linker, which could also have an effect on enzymatic activity. This has been shown before, e.g. for surface displayed sorbit dehydrogenase, with an altered substrate specicity of the surface displayed enzyme in comparison to the free molecule [43] or for prenyltransferase, for which surface display surprisingly increased the enzymatic activity in comparison to the free enzyme [8]. For comparing the activity of surface displayed CK $2 \alpha$ with the activity of the free enzyme, we first determined the number of $\mathrm{CK} 2 \alpha$ molecules per single cell of $E$. coli. For this purpose, the optical densities of the bands for $\mathrm{CK} 2 \alpha$, as well as for OmpA, were determined in lane 5 of the Coomassie stained SDS gel shown in Figure 2. The optical density of the CK2 $\alpha$-autotransporter fusion protein was 2.83 times higher than that of OmpA. Because OmpA is known to have a constant number of $10^{5}$ molecules per single cell [49], we could calculate the molecules of the CK $2 \alpha$-autotransporter fusion protein per single to be $1.1 \times 10^{5}$, by taking into consideration the different molecular weights of both proteins ( 95 and $35 \mathrm{kDa}$, respectively). Because the activity of a $200 \mu \mathrm{L}$ cell suspension of an $\mathrm{OD}_{578}=2$ (equals $1.72 \times 10^{8}$ cells/ $\mathrm{mL}$ ) without $\mathrm{NaCl}$ was $1.37 \times 10^{-5} \mu \mathrm{mol} / \mathrm{min}$, as indicated in Figure 5, the enzymatic activity of a single CK $2 \alpha$ molecule displayed at the cell surface was estimated to be $3.66 \times 10^{-18} \mu \mathrm{mol} / \mathrm{min}$. The enzymatic activity of free purified CK2 $\alpha$ was determined by CE under identical conditions with $0.2 \mu \mathrm{g}$ of protein in $200 \mu \mathrm{L}$. This resulted in an activity of $3.66 \times 10^{-5} \mu \mathrm{mol} / \mathrm{min}$. Taking the molecular weight of free CK2 $\alpha$ subunit into account, which is $45 \mathrm{kDa}$, an enzymatic activity of $1.16 \times 10^{-17} \mu \mathrm{mol} / \mathrm{min}$ per single molecule could be estimated. In summary the activity of surface displayed CK $2 \alpha$ was lowered by a factor of 3 in comparison to free CK $2 \alpha$ and hence, the influence of the linkage to the transport unit of autodisplay had only a moderate effect on substrate conversion.

\section{Conclusion}

Autodisplay of CK2 subunits clearly results in CK2 activity. Surface-displayed CK $2 \alpha$ and CK $2 \beta$ assemble on the cell surface to an active tetrameric holoenzyme. The whole-cell CK2 autodisplay assay is suitable for inhibition studies as demonstrated with the two selective CK2 inhibitors TBB and Silmitasertib. Furthermore, it can be used to determine quantitative CK2 inhibition data such as $\mathrm{IC}_{50}$ values. So far we could not detect any drawbacks in replacing the purified enzyme by the surface-displayed CK2 for in vitro assays. In fact, the easy and quick availability of CK2 activity avoids a laborious purification procedure and makes the CK2 autodisplay assay a valuable tool in early drug discovery and development.

\section{Authors' contributions}

JJ conceived of the study, guided its design and coordination and wrote parts of the manuscript. AG participated in the design of the study, determined the $\mathrm{IC}_{50}$ values and wrote parts of the manuscript, $\mathrm{AB}$ measured the $\mathrm{NaCl}$ dependency of CK2 activity and participated in writing the manuscript, CN made the immunoprecipitation experiments, SS performed the molecular cloning and expression analysis and CG determined the whole cell activities with the radiometric assay. ML contributed silmitasertib. All authors read and approved the final manuscript.

\section{Author details}

${ }^{1}$ Institut für Pharmazeutische und Medizinische Chemie, PharmaCampus, Westfälische Wilhelms-Universität Münster, Corrensstr. 48, 48149 Münster, Germany. ${ }^{2}$ Lehrstuhl für Biophysik, Ruhr-Universität Bochum, Universitätsstr. 150, 44801 Bochum, Germany. ${ }^{3}$ Université de Lyon, Université Lyon 1, Faculté de Pharmacie-ISPB, EA 4446 Biomolécules Cancer et Chimiorésistances, SFR Santé Lyon-Est CNRS UMS3453-INSERM US7, 69373 Lyon Cedex 8, France.

${ }^{4}$ Medizinische Biochemie und Molekularbiologie, Universität des Saarlandes, Kirrberger Str., Geb. 44, 66421 Homburg, Germany.

\section{Acknowledgements}

Many thanks to Ilka Rauch for helpful technical assistance.

Compliance with ethical guidelines

\section{Competing interests}

The authors declare that they have no competing interests.

Received: 20 March 2015 Accepted: 11 May 2015

Published online: 03 June 2015

\section{References}

1. van Bloois E, Winter RT, Kolmar H, Fraaije MW (2011) Decorating microbes: surface display of proteins on Escherichia coli. Trends Biotechnol 29(2):79-86. doi:10.1016/j.tibtech.2010.11.003

2. Raaf J, Guerra B, Neundorf I, Bopp B, Issinger O-G, Jose J et al (2013) First structure of protein kinase CK2 catalytic subunit with an effective CK2 $\beta$ competitive ligand. ACS Chem Biol 8(5):901-907. doi:10.1021/cb3007133

3. Daugherty PS, Chen G, Olsen MJ, Iverson BL, Georgiou G (1998) Antibody affinity maturation using bacterial surface display. Protein Eng 11(9):825-832

4. Salema V, Marin E, Martinez-Arteaga R, Ruano-Gallego D, Fraile S, Margolles $Y$ et al (2013) Selection of single domain antibodies from immune libraries displayed on the surface of $E$. coli cells with two beta-domains of opposite topologies. PLoS One 8(9):e75126. doi:10.1371/journal. pone.0075126 
5. Jose J, Betscheider D, Zangen D (2005) Bacterial surface display library screening by target enzyme labeling: identification of new human cathepsin G inhibitors. Anal Biochem 346(2):258-267. doi:10.1016/j. ab.2005.08.019

6. Kenrick SA, Daugherty PS (2010) Bacterial display enables efficient and quantitative peptide affinity maturation. Protein Eng Des Sel 23(1):9-17. doi:10.1093/protein/gzp065

7. Jose J, Maas RM, Teese MG (2012) Autodisplay of enzymes_molecular basis and perspectives. J Biotechnol 161(2):92-103. doi:10.1016/j. jbiotec.2012.04.001

8. Kranen E, Steffan N, Maas RM, Li SM, Jose J (2011) Development of a whole cell biocatalyst for the efficient prenylation of indole derivatives by Autodisplay of the aromatic prenyltransferase FgaPT2. ChemCatChem 3:1200-1207

9. Jose J, Bernhardt R, Hannemann F (2002) Cellular surface display of dimeric Adx and whole cell P450-mediated steroid synthesis on E. coli. J Biotechnol 95(3):257-268. doi:10.1016/S0168-1656(02)00030-5

10. Schumacher SD, Jose J (2012) Expression of active human P450 3A4 on the cell surface of Escherichia coli by autodisplay. J Biotechnol 161(2):113120. doi:10.1016/j.jbiotec.2012.01.031

11. Jose J, Meyer TF (2007) The autodisplay story, from discovery to biotechnical and biomedical applications. Microbiol Mol Biol Rev 71(4):600-619. doi:10.1128/MMBR.00011-07

12. Wilhelm S, Rosenau F, Kolmar H, Jaeger KE (2011) Autotransporters with GDSL passenger domains: molecular physiology and biotechnological applications. ChemBioChem 12(10):1476-1485. doi:10.1002/ cbic.201100013

13. Smith M, Khera E, Fei W (2015) Engineering novel and improved biocatalysts by cell surface display. Ind Eng Chem Res. doi:10.1021/ie504071f

14. Jose J, Bernhardt R, Hannemann F (2001) Functional display of active bovine adrenodoxin on the surface of $E$. coli by chemical incorporation of the [2Fe-2S] cluster. ChemBioChem 2(9):695-701. doi:10.1002/1439-7633(20010903)2:9<695

15. Jose J, Handel S (2003) Monitoring the cellular surface display of recombinant proteins by cysteine labeling and flow cytometry. ChemBioChem 4(5):396-405. doi:10.1002/cbic.200200530

16. Detzel C, Maas RM, Jose J (2011) Autodisplay of nitrilase from Alcaligenes faecalis in E. coli yields a whole cell biocatalyst for the synthesis of enantiomerically pure R-mandelic acid. ChemCatChem 3:719-725

17. Kranen E, Detzel C, Weber T, Jose J (2014) Autodisplay for the co-expression of lipase and foldase on the surface of $E$. colli: washing with designer bugs. Microb Cell Fact 13:19. doi:10.1186/1475-2859-13-19

18. Trembley JH, Chen Z, Unger G, Slaton J, Kren BT, Van Waes C et al (2010) Emergence of protein kinase CK2 as a key target in cancer therapy. BioFactors 36(3):187-195. doi:10.1002/biof.96

19. Cozza G, Pinna LA, Moro S (2012) Protein kinase CK2 inhibitors: a patent review. Expert Opin Ther Pat 22(9):1081-1097. doi:10.1517/13543776.201 2.717615

20. Siddiqui-Jain A, Drygin D, Streiner N, Chua P, Pierre F, O'Brien SE et al (2010) CX-4945, an orally bioavailable selective inhibitor of protein kinase CK2, inhibits prosurvival and angiogenic signaling and exhibits antitumor efficacy. Cancer Res 70(24):10288-10298. doi:10.1158/0008-5472. CAN-10-1893

21. Pierre F, Chua PC, O'Brien SE, Siddiqui-Jain A, Bourbon P, Haddach M et al (2011) Pre-clinical characterization of CX-4945, a potent and selective small molecule inhibitor of CK2 for the treatment of cancer. Mol Cell Biochem 356(1-2):37-43. doi:10.1007/s11010-011-0956-5

22. Cozza G, Pinna LA, Moro S (2013) Kinase CK2 inhibition: an update. Curr Med Chem 20(5):671-693. doi:10.2174/092986713804999312

23. Studier FW, Moffatt BA (1986) Use of bacteriophage T7 RNA polymerase to direct selective high-level expression of cloned genes. J Mol Biol 189(1):113-130

24. Hantke K (1981) Regulation of ferric iron transport in Escherichia coli K12: isolation of a constitutive mutant. Mol Gen Genet 182(2):288-292

25. Schumacher SD, Hannemann F, Teese MG, Bernhardt R, Jose J (2012) Autodisplay of functional CYP106A2 in Escherichia coli. J Biotechnol 161(2):104-112. doi:10.1016/j.jbiotec.2012.02.018

26. Bong JH, Yoo G, Park M, Kang MJ, Jose J, Pyun JC (2014) Ultrasonic isolation of the outer membrane of Escherichia coli with autodisplayed Z-domains. Enzyme Microb Technol 66:42-47. doi:10.1016/j. enzmictec.2014.08.006
27. Faust M, Gunther J, Morgenstern E, Montenarh M, Gotz C (2002) Specific localization of the catalytic subunits of protein kinase CK2 at the centrosomes. Cell Mol Life Sci 59(12):2155-2164

28. Schuster N, Götz C, Faust M, Schneider E, Prowald A, Jungbluth A et al (2001) Wild-type p53 inhibits protein kinase CK2 activity. J Cell Biochem 81(1):172-183

29. Gratz A, Götz C, Jose J (2010) A CE-based assay for human protein kinase CK2 activity measurement and inhibitor screening. Electrophoresis 31(4):634-640. doi:10.1002/elps.200900514

30. Kuenzel EA, Mulligan JA, Sommercorn J, Krebs EG (1987) Substrate specificity determinants for casein kinase II as deduced from studies with synthetic peptides. J Biol Chem 262(19):9136-9140

31. Held D, Yaeger K, Novy R (2003) New coexpression vectors for expanded compatibilities in E. coli. InNovations 18:4-6

32. Guillon J, Le Borgne M, Rimbault C, Moreau S, Savrimoutou S, Pinaud $\mathrm{N}$ et al (2013) Synthesis and biological evaluation of novel substituted pyrrolo[1,2-a]quinoxaline derivatives as inhibitors of the human protein kinase CK2. Eur J Med Chem 65:205-222. doi:10.1016/j. ejmech.2013.04.051

33. Lattemann CT, Maurer J, Gerland E, Meyer TF (2000) Autodisplay: functional display of active beta-lactamase on the surface of Escherichia coli by the AIDA-I autotransporter. J Bacteriol 182(13):3726-3733

34. Maurer J, Jose J, Meyer TF (1999) Characterization of the essential transport function of the AIDA-I autotransporter and evidence supporting structural predictions. J Bacteriol 181(22):7014-7020

35. Glover CV (1986) A filamentous form of Drosophila casein kinase II. J Biol Chem 261(30):14349-14354

36. Valero E, De Bonis S, Filhol O, Wade RH, Langowski J, Chambaz EM et al (1995) Quaternary structure of casein kinase 2. Characterization of multiple oligomeric states and relation with its catalytic activity. J Biol Chem 270(14):8345-8352

37. Niefind K, Raaf J, Issinger O-G (2009) Protein kinase CK2 in health and disease: protein kinase CK2: from structures to insights. Cell Mol Life Sci 66(11-12):1800-1816. doi:10.1007/s00018-009-9149-8

38. Lolli G, Ranchio A, Battistutta R (2014) Active form of the protein kinase CK2 alpha2beta2 holoenzyme is a strong complex with symmetric architecture. ACS Chem Biol 9(2):366-371. doi:10.1021/cb400771y

39. Dobrowolska G, Lozeman FJ, Li D, Krebs EG (1999) CK2, a protein kinase of the next millennium. Mol Cell Biochem 191(1-2):3-12

40. Hofinger ESA, Spickenreither M, Oschmann J, Bernhardt G, Rudolph R, Buschauer A (2007) Recombinant human hyaluronidase Hyal-1: insect cells versus Escherichia coli as expression system and identification of low molecular weight inhibitors. Glycobiology 17(4):444-453. doi:10.1093/ glycob/cwm003

41. Kaessler A, Olgen S, Jose J (2011) Autodisplay of catalytically active human hyaluronidase $\mathrm{hPH}-20$ and testing of enzyme inhibitors. Eur J Pharm Sci 42(1-2):138-147. doi:10.1016/j.ejps.2010.11.004

42. Meggio F, Boldyreff B, Marin O, Pinna LA, Issinger O-G (1992) Role of the beta subunit of casein kinase-2 on the stability and specificity of the recombinant reconstituted holoenzyme. Eur J Biochem 204(1):293-297

43. Jose J, von Schwichow S (2004) Autodisplay of active sorbitol dehydrogenase (SDH) yields a whole cell biocatalyst for the synthesis of rare sugars. ChemBioChem 5(4):491-499. doi:10.1002/cbic.200300774

44. Detzel C, Maas R, Tubeleviciute A, Jose J (2012) Autodisplay of nitrilase from Klebsiella pneumoniae and whole-cell degradation of oxynil herbicides and related compounds. Appl Microbiol Biotechnol 97(11):48874896. doi:10.1007/s00253-012-4401-9

45. Niefind K, Guerra B, Ermakova I, Issinger O-G (2000) Crystallization and preliminary characterization of crystals of human protein kinase CK2. Acta Crystallogr D Biol Crystallogr 56(Pt 12):1680-1684

46. Guerra B, Niefind K, Ermakova I, Issinger O-G (2001) Characterization of CK2 holoenzyme variants with regard to crystallization. Mol Cell Biochem 227(1-2):3-11

47. Ermakova I, Boldyreff B, Issinger O-G, Niefind K (2003) Crystal structure of a C-terminal deletion mutant of human protein kinase CK2 catalytic subunit. J Mol Biol 330(5):925-934

48. Watanabe K, Tomioka S, Tanimura K, Oku H, Isoi K (2011) Uptake of AMP, ADP, and ATP in Escherichia coli W. Biosci Biotechnol Biochem 75(1):7-12

49. Koebnik R, Locher KP, Van Gelder P (2000) Structure and function of bacterial outer membrane proteins: barrels in a nutshell. Mol Microbiol 37:239-253 